\title{
GROWTH OF ARBOREAL LEGUMINOUS PLANTS AND MAIZE YIELD IN AGROFORESTRY SYSTEMS ${ }^{1}$
}

Vianney Reinaldo de Oliveira ${ }^{2}$, Paulo Sérgio Lima e Silva ${ }^{3 *}$, Haroldo Nogueira de Paiva ${ }^{4}$, Frederico Silva Thé Pontes ${ }^{5}$ and Rafaela Priscila Antonio ${ }^{6}$

\footnotetext{
${ }^{1}$ Received on 26.11.2013 accepted for publication on 20.05.2016.

${ }^{2}$ Universidade Federal Rural do Semi-Árido, Programa de Pós-Graduação em Fitotecnia, Mossoró, RN - Brasil. E-mail: $<$ vianney.reinaldo@gmail.com>.

${ }^{3}$ Universidade Federal Rural do Semi-Árido, Departamento de Ciências Vegetais, Mossoró, RN - Brasil. E-mail: <paulosergio@ufersa.edu.br>.

${ }^{4}$ Universidade Federal de Viçosa, Centro de Ciências Agrárias, Departamento de Engenharia Florestal, Viçosa, MG - Brasil. E-mail: <hnpaiva@ufv.br>.

${ }^{5}$ Universidade Federal Rural do Semi-Árido, Departamento de Agroecologia e Ciências Sociais, Mossoró, RN - Brasil. E-mail:<fredericothe@hotmail.com>.

${ }^{6}$ Embrapa Semiárido, CPATSA, Petrolina, PE - Brasil. E-mail: <rafaela.antonio@embrapa.br>.

*Corresponding author.
}

\begin{abstract}
Forest plantation costs can be reduced by the income from annual crops that are intercropped with trees. An experiment was carried out over two years to assess the viability of agroforestry systems including sabiá (Mimosa caesalpiniifolia), gliricidia (Gliricidia sepium) and maize (cultivar AG 1051). In 2010, the legumes were grown both as monocrops and intercropped (taungya system) with maize in randomized blocks with five replications. Three rows of maize were planted between two rows of each legume (at a spacing of $4.0 \mathrm{~m} \mathrm{x} 4.0 \mathrm{~m}$ ). In 2011, the legumes were cut down, and the young branches and leaves were added to the areas of intercropped cultivation (alley cropping system). Gliricidia had lower plant height than sabiá. Moreover, while not affecting for gliricidia, intercropping increased plant height for sabiá. Intercropping reduced green ear yield but not grain yield and reduced the cost of introducing reforestation. Intercropping using the alley system reduced the total number and mass of green ears, as well as grain yield, but did not influence the yield of marketable green ears. Finally, producing green ears was more profitable than producing grain and maize monocropping provided a higher net income than intercropping.
\end{abstract}

Keywords: Mimosa caesalpiniifolia; Gliricidia sepium; Zea mays.

\section{CRESCIMENTO DE LEGUMINOSAS ARBÓREAS E RENDIMENTO DO MILHO EM SISTEMAS AGROFLORESTAIS}

\begin{abstract}
RESUMO - Os custos de plantios florestais podem ser reduzidos com a renda de culturas consorciadas com as espécies arbóreas. Um experimento foi realizado nos anos 2010 e 2011 para avaliar a viabilidade de dois sistemas agroflorestais envolvendo leguminosas (sabiá e gliricídia) e milho (cultivar AG 1051). Em 2010, as leguminosas foram cultivadas em monocultivo e em consorciação (sistema taungya) com o milho, em blocos ao acaso com cinco repetições. Três fileiras de milho foram plantadas entre duas fileiras das leguminosas (espaçamento 4,0 $\mathrm{m} \times$ 4,0 m). Em 2011, as leguminosas foram cortadas a 0,5 $\mathrm{m}$ do nível do solo, e os ramos jovens e folhas foram incorporados nas áreas cultivadas em consórcio (sistema aléias). A consorciação aumenta a altura da planta (AP) na sabiá, mas não na gliricídia. A gliricídia tem menor AP do que a sabiá. A consorciação reduz o rendimento de espigas verdes, mas não o rendimento de grãos. A consorciação com milho reduz os custos de implantação do reflorestamento, especialmente com a venda de espigas verdes. Em aleias, a consorciação reduz o número e a massa totais de espigas verdes e o rendimento de grãos, mas não influencia o rendimento de espigas verdes comercializáveis. Produzir espigas verdes é mais vantajoso do que produzir grãos. O monocultivo do milho proporciona maior renda do que a consorciação.
\end{abstract}

Palavras-chave: Mimosa caesalpiniifolia; Gliricidia sepium; Zea mays. 


\section{INTRODUCTION}

The Caatinga is a biome that spans $735,000 \mathrm{~km}^{2}$, covering most of the states of northeastern Brazil and the northeastern portion of the state of Minas Gerais. Estimates indicate that $30 \%$ to $51 \%$ of the area of the Caatinga has been altered by human activity (CASTELLETTI et al., 2004). This suggests that the Caatinga is the third most degraded ecosystem in Brazil, after the Atlantic Forest region and the Cerrado (LEAL et al., 2005).

Reforestation may contribute to solve the degradation of the Caatinga by reducing deforestation and by serving as a source of income through wood exploitation, among other benefits. However, the initial investment to plant trees is high, and reforestation requires time to generate profit given the perennial nature of tree species. One solution to this problem would be to adopt agroforestry systems where woody species are used together with agricultural crops and/ or animals in the same area.

Upon adopting agroforestry systems, one of the most important decisions is choosing the species to be included in them. Mimosa caesalpiniifolia Benth., popularly known as sabiá, is a rustic leguminous plant with multiple uses, adapted to a semiarid climate. Another species of tree that could be used in agroforestry systems designed for the Caatinga is gliricidia (Gliricidia sepium (Jacq.) Kunth ex Walp.). Although non-native, gliricidia has characteristics similar to sabiá and has been used in agroforestry systems virtually all over the world (KIILL; MENEZES, 2005). Maize (Zea mays L.) stands out among the annual species that could be included in agroforestry systems as it is an easily cultivated well-known crop to farmers, with no major pest or disease problems and a short life cycle.

Taungya, the agroforestry system most used in Brazil (SILVA et al., 2001), is based on two components: permanent forest and temporary agricultural crops (IMO, 2009). The main objective of intercropping forest species with annual crops is to optimize production and economic return (EHIAGBONARE, 2006). Thus, several authors have studied the economic benefits of the taungya system (RODRIGUES et al., 2007; DARONCO et al., 2012).

Closing the tree canopy after one or more years prevents the taungya method from undergoing continued evaluation. Closing provides the opportunity to study alley cropping, another type of agroforestry system where trees or shrubs associated with nitrogen-fixing bacteria are grown in rows interspersed with agricultural crops. The trees are pruned at the beginning of the growing season for the main crop, and the most tender leaves and branches are added to the soil, similar to green manure. Queiroz et al. (2007) determined that maize grain yield depended on the species of intercropped trees, and that maize intercropped with gliricidia and monocropped maize had similar yields.

This study aimed to evaluate the agronomic and economic viability of intercropping sabiá and gliricidia with maize using the taungya system for the first year, and to assess maize yield using alley cropping for the second year.

\section{MATERIAL AND METHODS}

The experiment was carried out in 2010 and 2011 at $5^{\circ} 11^{\prime} \mathrm{S}, 37^{\circ} 20^{\prime} \mathrm{W}$ at an altitude of $18 \mathrm{~m}$. In 2010 , maize, gliricidia and sabiá were evaluated, both under mono and intercropping. In 2011, the intercropped trees were pruned, as the crown diameter no longer allowed for intercropping. The resulting leaves and young branches were added to the soil between the rows of trees, and maize was grown in these areas. The region has a BSwh bioclimate, i.e., hot-type (KÖPPEN, 1948), with a maximum average air temperature of $32.1-34.5^{\circ} \mathrm{C}$ (June and July being the coldest months), and an average annual rainfall of approximately 825 mm (CARMO FILHO; OLIVEIRA, 1989).

On 14 April 2010, tree seeds were sown in black plastic bags ( $20 \mathrm{~cm}$ in length and $15 \mathrm{~cm}$ of diameter), a third of the bags being perforated at the bottom. The bags were filled with a substrate comprised of $1 / 3$ cattle manure and $2 / 3$ soil. The soil was classified as Red-Yellow Argisol (EMBRAPA, 2006) and as Ferric Lixisol (FAO, 1988). Analysis of a soil sample from the experimental area showed: $\mathrm{pH}=7.6 ; \mathrm{Ca}=2.20$ $\mathrm{cmol}_{\mathrm{c}} \mathrm{dm}^{-3} ; \mathrm{Mg}=0.00 \mathrm{cmol}_{\mathrm{c}} \mathrm{dm}^{-3} ; \mathrm{K}=223.1 \mathrm{mg} \mathrm{dm}^{-3}$; $\mathrm{Na}=99.7 \mathrm{mg} \mathrm{dm}^{-3} ; \mathrm{Al}=0.00 \mathrm{cmol} \mathrm{dm}_{\mathrm{c}}^{-3} ; \mathrm{P}=22.6 \mathrm{mg}$ $\mathrm{dm}^{-3}$; Organic Matter $=15.86 \mathrm{~g} \mathrm{~kg}^{-1}$. The soil of the experimental area was prepared by harrowing twice. Tree seedlings were transplanted into holes $(0.2 \mathrm{~m}$ x $0.2 \mathrm{~m} \mathrm{x} 0.2 \mathrm{~m}$ ) and one month after sowing, into a soil of the same type as described above, in an area previously cultivated with maize. No fertilization was applied to the tree species. 
The following treatments were evaluated in randomized blocks with five replications: monocropping of sabiá (S), gliricidia (G) and maize (M), and intercropping of $S+M$, and $G+M$. The plots were made of three rows for $\mathrm{S}$ and $\mathrm{G}$, each containing four plants spaced $4.0 \mathrm{~m} \mathrm{x} 4.0 \mathrm{~m}$ (625 plants ha $\left.{ }^{-1}\right)$. The area occupied by the two central plants of the central row was considered usable area. The maize monocrop was grown in plots of four rows (of $12.0 \mathrm{~m}$ in length), spaced $1.0 \mathrm{~m} \times 0.4$ $\mathrm{m}$ apart $\left(50,000\right.$ plants $\left.\mathrm{ha}^{-1}\right)$ and placed on the right side of each replication at a distance of $5.0 \mathrm{~m}$ from the neighboring plot. The area occupied by the two central rows, disregarding the plants from either end of each row, was considered usable area. For intercropping, trees were grown in plots similar to those used in the monocrops. The maize was sown in three rows between every two rows of legumes, using the same spacing as in monocropping.

Maize was sown on 18 May 2010 using four seeds hole $^{-1}$ of the cultivar AG 1051. Thinning was carried out 20 days after sowing, leaving the two more vigorous plants in each hole. After thinning, maize-planting density was 37,500 plants $\mathrm{ha}^{-1}$ and 50,000 plants ha $\mathrm{h}^{-1}$ for intercropping and monocropping, respectively. Before sowing the maize, $40 \mathrm{~kg} \mathrm{~N} \mathrm{ha}^{-1}$ (ammonium sulfate), $60 \mathrm{~kg} \mathrm{P}_{2} \mathrm{O}_{5} \mathrm{ha}^{-1}$ (single superphosphate) and $30 \mathrm{~kg} \mathrm{~K}_{2} \mathrm{O}$ $\mathrm{ha}^{-1}$ (potassium chloride) were applied in grooves located adjacent to and below the seeding rows. The remaining nitrogen ( $\left.80 \mathrm{~kg} \mathrm{~N} \mathrm{ha}^{-1}\right)$ was applied in two stages, in equal amounts and as cover after each weeding.

The experiment was conducted under rainfed conditions, using sprinkler irrigation when needed. The water depth required daily by maize $(5.6 \mathrm{~mm})$ was calculated considering $0.40 \mathrm{~m}$ as the effective depth of the root system. The decision of when to irrigate was based on the water retained in the soil at a tension of $0.40 \mathrm{Mpa}$. The irrigation interval was two days, with three weekly applications. Irrigation started after planting and was suspended 15 days before harvesting the dry maize. The caterpillar Spodoptera frugiperda (Smith) was controlled by spraying Lannat BR $\left(600 \mathrm{ml} \mathrm{ha}^{-1}\right)$ and Rimon $100 \mathrm{EC}\left(150 \mathrm{ml} \mathrm{ha}^{-1}\right)$ on days 14 and 30 after sowing. Weeds were controlled by hoeing on days 20 and 40 after sowing.

Plant height and diameter of stem and crown (at $10 \mathrm{~cm}$ above the ground level, measured with calipers) were evaluated for the two usable plants of the tree species at the time of transplant and each month thereafter. Plant height was measured as the distance from the ground level to the highest part of the tree. Diameter of stem and crown were estimated as the average of two perpendicular measurements, one being in the direction of the row.

Green corn yield, grain (dry corn) yield, plant height and ear height were estimated for maize. For monocropping, one of the two usable rows was used to evaluate green-ear yield, and the other to estimate grain yield. For intercropping, one of the two areas adjacent to the central row of each legume, occupied by the three rows of maize, was taken at random for evaluation of green ear yield, and the other was used to evaluate grain yield and its components. Green corn was harvested on days 73, 76 and 79 after sowing. Green corn yield was evaluated by counting and weighing the total and marketable ears, with and without the husk. Ears with husks that had good appearance, no marks or signs of disease or pests, and a length equal to or greater than $23 \mathrm{~cm}$ were considered marketable. Healthy ears without husks with grains suitable for commercialization and a length equal to or greater than $18 \mathrm{~cm}$ were considered marketable. After harvesting the green ears, plant height and ear height were evaluated in 26 plants. Plant height was defined as the distance from the ground level to the point of insertion of the highest leaf. Ear height was measured from the ground level to the insertion node of the highest ear.

The number of mature ears ha-1 was estimated from the number of ears harvested in the usable area. The number of grains per ear was estimated for ten ears picked randomly from those harvested in each plot. Based on the weight and number of grains for ten ears, the 100grain weight was also estimated. Grain yield was corrected for a moisture content of $15.5 \%$ (wet weight).

On 4 March 2011, trees from plots cultivated the previous year under intercropping were cut down to $0.5 \mathrm{~m}$ from the ground level. Pruned leaves and branches with a diameter of less than approximately $1.0 \mathrm{~cm}$ were evenly distributed over the two areas between the three rows of cut gliricidia and sabiá. The material was added to the soil by disc harrowing, followed by sowing the maize. Three groups were evaluated as described above: the maize monocrop, intercropped corn and cut gliricidia, and intercropped corn and cut sabiá. The experiment was conducted under rainfed conditions, but emergency irrigation of maize was necessary due to uneven rainfall distribution at the beginning of the experimental period.

Revista Árvore, Viçosa-MG, v.40, n.4, p.679-688, 2016 
The data were tested for normality of residual distribution using the Lilliefors' test (LILLIEFORS, 1967) and for homogeneity of variance using the Bartlett's test (BARTLETT, 1937). Plant height and stem and crown diameter of the tree species were measured as in the experiment with split plots and the data were submitted to variance (ANOVA) and regression analyses. Data from green corn and grain yields were subjected to variance analysis. ANOVA (F test) was used to compare between two averages and ANOVA followed by Tukey's test was used to compare between three averages. Variance analysis was carried out using the SISVAR software, version 5.3, developed by UFLA (FERREIRA, 2010). Regression analysis was performed using the software created by Jandel (1992).

An economic evaluation was performed, following methodologies of cost and profitability, and considering the production costs of green ears and grain under intercropping with gliricidia and sabiá, as well as the costs for planting these tree species (REIS, 2002). The costs considered in the analysis included variable costs, fixed costs, operating costs and total costs (CONAB, 2010). A variable cost is a cost that varies in relation to changes in activity volume. Fixed costs are those that fall into the producer's expenses, regardless of production volume, such as depreciation, insurance, periodic maintenance of machines and others. The operating cost consists of all variable costs added by the share of fixed costs directly associated with implementation of the crop. It differs from total cost, as it does not contemplate the income of fixed factors, regarded as the expected return on fixed capital and on earth. The opportunity cost is defined as the value of a forgone activity or alternative when another item or activity is chosen. Total cost of production is the sum of operating costs plus the compensation attributed to production factors. The tree planting costs of mono or intercropping were compared. The resulting difference represents the cost reduction of planting tree species. To evaluate the set-up costs for intercropping, the equation $\mathrm{TC}_{\mathrm{AC}}=\left(\mathrm{C}_{\mathrm{ANNUAL}}+\mathrm{C}_{\mathrm{TREE}}\right)-\mathrm{R}_{\mathrm{ANNUAL}}$ was used, where: $\mathrm{TC}_{\mathrm{AC}}=$ total cost per hectare for the introduction of tree species intercropped with maize; $\mathrm{C}_{\mathrm{ANNUAL}}=$ operating cost per hectare for the production of maize under intercropping; $\mathrm{C}_{\mathrm{TREE}}=$ operating cost per hectare for the production of tree species under intercropping; $\mathrm{R}_{\mathrm{ANNUAL}}=$ total revenue per hectare for maize under intercropping. Prices for inputs, and for green and dry maize were obtained at the beginning of November 2010 in the marketplace and from producers in Mossoró (Rio Grande do Norte, Brazil) respectively. Prices (in Brazilian Reais) per kilogram were $\mathrm{R} \$ 0.73$ and $\mathrm{R} \$ 0.55$ for marketable husked ears of green corn and for dried corn grain, respectively.

\section{RESULTS}

Sabiá had greater plant height than gliricidia, under both monocropping and intercropping conditions (Table 1). While plant height was not affected by the cropping system for gliricidia, intercropping with maize was associated with greater plant height for sabiá. Plant age was the only factor affecting the diameter of the tree crown. The canopy diameter of the two species increased under the two cropping systems in response to time of evaluation (Table 2). Stem diameter was affected by species (E), cropping system (S), evaluation (A) and the interactions $\mathrm{E} \times \mathrm{S}, \mathrm{E} \times \mathrm{A}, \mathrm{S} \times \mathrm{A}$ and $\mathrm{E} \times \mathrm{S} \times$ A. Gliricidia had a greater stem diameter than sabiá, under both cropping systems (Table 1). Sabiá stem

Table1 - Averages for plant height and for crown and root collar diameter of tree species under monocropping and intercropping with the maize cultivar AG 1051 on day 120 after maize sowing.

Tabela 1 - Médias para a altura da planta e diâmetros da copa e do colo de espécies arbóreas, em monocultivo e em consorciação com a cultivar de milho $A G$ 1051, aos 120 dias após a semeadura do milho.

\begin{tabular}{|c|c|c|}
\hline \multirow[t]{3}{*}{ Tree species } & \multicolumn{2}{|c|}{ Cropping system } \\
\hline & Monocropping & Intercropping \\
\hline & \multicolumn{2}{|c|}{ Plant height $(\mathrm{cm})$} \\
\hline Gliricidia & $56 \mathrm{bA}$ & $58 \mathrm{bA}$ \\
\hline Sabiá & $71 \mathrm{aB}$ & $91 \mathrm{aA}$ \\
\hline \multicolumn{3}{|c|}{ Experimental coefficient of variation $=\mathrm{CV}=32.5 \%$} \\
\hline & \multicolumn{2}{|c|}{ Crown diameter $(\mathrm{cm})$} \\
\hline Gliricidia & 67 aA & 59 aA \\
\hline Sabiá & 62 aA & 69 aA \\
\hline \multicolumn{3}{|l|}{$\mathrm{CV}=28.2 \%$} \\
\hline & \multicolumn{2}{|c|}{ Root collar diameter $(\mathrm{mm})$} \\
\hline Gliricidia & $13.7 \mathrm{aA}$ & $10.8 \mathrm{aB}$ \\
\hline Sabiá & $9.2 \mathrm{bA}$ & $9.2 \mathrm{bA}$ \\
\hline
\end{tabular}

Averages followed by the same lower-case letter in the columns and by the same upper-case letter in the rows do not differ by the Ftest at $5 \%$ probability.

Médias seguidas pela mesma letra minúscula, nas colunas, e pela mesma letra maiúscula, nas linhas, não diferem entre si, a 5\% de probabilidade, pelo teste $F$. 
Table 2 - Averages for plant height and for crown and root collar diameters of tree species under monocropping and intercropping with maize, as a function of plant age.

Tabela 2 - Médias da altura da planta e diâmetros da copa e do colo de espécies arbóreas, em monocultivo e em consorciação com a cultivar de milho AG 1051, em função da idade da planta.

\begin{tabular}{|c|c|c|c|c|c|c|c|c|c|c|c|c|}
\hline \multirow[t]{3}{*}{ Tree species } & \multirow[b]{2}{*}{0} & \multicolumn{8}{|c|}{ Plant age (days after sowing, $\mathrm{x}$ ) } & \multicolumn{3}{|c|}{ Regression analysis } \\
\hline & & 30 & 60 & 90 & 120 & 150 & 180 & 210 & 240 & 270 & Equation & $\mathrm{R}^{2}$ \\
\hline & & & & & & & & & & \multicolumn{3}{|c|}{ Plant height, y $(\mathrm{cm})$} \\
\hline Gliricidia monocrop & 0.0 & 21.9 & 45.6 & 85.5 & 126.1 & 160.1 & 201.4 & 229.8 & 256.4 & 306.9 & $\mathrm{y}^{0.5}=-1.55^{*}+1.15^{*} \mathrm{x}^{0.5}$ & 0.99 \\
\hline Sabiá monocrop & 0.0 & 50.3 & 59.2 & 103.7 & 143.1 & 172.9 & 203.3 & 220.9 & 242.5 & 278.7 & $\mathrm{y}=1.28^{*} \mathrm{x}-0.00096^{*} \mathrm{x}^{2}$ & 0.91 \\
\hline Gliricidia intercrop & 0.0 & 20.8 & 46.0 & 91.8 & 131.9 & 153.9 & 184.9 & 209.8 & 237.7 & 272.1 & $\mathrm{y}=-3.86+1.03^{*} \mathrm{x}$ & 0.90 \\
\hline Sabiá intercrop & 0.0 & 38.9 & 77.7 & 144.4 & 192.3 & 223.0 & 258.0 & 290.9 & 312.4 & 339.3 & $\mathrm{y}=1.74^{*} \mathrm{x}-0.0017^{*} \mathrm{x}^{2}$ & 0.95 \\
\hline \multicolumn{13}{|c|}{ Experimental coefficient of variation (plots) $=43.6 \%$} \\
\hline \multicolumn{13}{|c|}{ Experimental coefficient of variation (subplots) $=11.5 \%$} \\
\hline & & & & & & & & & & \multicolumn{3}{|c|}{ Canopy diameter, $\mathrm{y}(\mathrm{cm})$} \\
\hline Gliricidia monocrop & 0.0 & 28.0 & 60.6 & 111.6 & 134.2 & 152.7 & 184.9 & 215.5 & 264.5 & 313.0 & $\mathrm{y}=0.81^{*} \mathrm{x}^{1.06^{*}}$ & 0.96 \\
\hline Sabiá monocrop & 0.0 & 27.7 & 50.3 & 104.0 & 125.8 & 149.7 & 171.0 & 190.5 & 222.0 & 284.6 & $\mathrm{y}=0.36+0.98^{*} \mathrm{x}$ & 0.89 \\
\hline Gliricidia intercrop & 0.0 & 25.6 & 55.5 & 99.0 & 115.8 & 128.9 & 147.6 & 176.6 & 223.5 & 254.8 & $\mathrm{y}=1.16^{*} \mathrm{x}^{0.96^{*}}$ & 0.92 \\
\hline Sabiá intercrop & 0.0 & 25.0 & 65.9 & 116.9 & 137.9 & 180.3 & 213.9 & 261.3 & 284.8 & 331.7 & $\mathrm{y}=-5.01+1.24^{*} \mathrm{x}$ & 0.87 \\
\hline \multicolumn{13}{|c|}{ Experimental coefficient of variation (plots) $=53.4 \%$} \\
\hline \multicolumn{13}{|c|}{ Experimental coefficient of variation (subplots) $=15.7 \%$} \\
\hline & & & & & & & & & & \multicolumn{3}{|c|}{ Root collar diameter, $\mathrm{y}(\mathrm{mm})$} \\
\hline Gliricidia monocrop & 0.0 & 4.32 & 11.99 & 22.41 & 29.86 & 36.6 & 44.83 & 49.96 & 55.09 & 62.47 & $y=0.25 x-0.00006^{*} x^{2}$ & 0.97 \\
\hline Sabiá monocrop & 0.0 & 3.50 & 7.74 & 14.93 & 19.94 & 25.02 & 30.15 & 32.85 & 35.30 & 39.23 & $\mathrm{y}=0.17^{*} \mathrm{x}-0.25^{*} \mathrm{x}^{2}$ & 0.90 \\
\hline Gliricidia intercrop & 0.0 & 4.06 & 9.66 & 17.93 & 22.26 & 27.37 & 32.49 & 37.05 & 41.60 & 47.64 & $\mathrm{y}=0.19 \mathrm{x}-0.00005^{*} \mathrm{x}^{2}$ & 0.97 \\
\hline Sabiá intercrop & 0.0 & 2.75 & 8.60 & 15.05 & 19.46 & 26.22 & 31.29 & 36.45 & 40.59 & 43.86 & $\mathrm{y}=-0.88+0.17^{*} \mathrm{x}$ & 0.89 \\
\hline
\end{tabular}

Experimental coefficient of variation (plots) $=40.5 \%$

Experimental coefficient of variation (subplots) $=12.0 \%$

* Significant at $5 \%$ probability by t-test.

* Significativo a $5 \%$ de probabilidade pelo teste $t$.

diameter was not influenced by the cropping system, but gliricidia stem diameter decreased when intercropping with maize (Table 1). As with plant height and crown diameter, stem diameter increased as a function of plant age (Table 2). Intercropping had different effects on growth of the two tree species, reducing stem diameter only in gliricidia (Table 1). This was most likely the result of competition with the maize for light, nutrients, and water (despite irrigation). The curves adjusted for plant height, canopy diameter and base diameter were not always linear (Table 2). However, during the studied period (up to 270 days after planting), the three characteristics increased practically in a linear fashion with plant age. Maximum values for the three characteristics were observed on day 270 after planting, for the four farming systems.

The cropping system had no effect on plant height (average $174 \mathrm{~cm}$, experimental coefficient of variation,
$\mathrm{CV}=6.4 \%$ ) or ear height (average $90 \mathrm{~cm}, \mathrm{CV}=8.3 \%$ ) for maize. Four meters spacing between the legumes was used in each row, which may have promoted reduced competition between the trees and maize. Karim et al. (1993) found that reducing the spacing between G. sepium plants in rows can decrease the yield of co-cultured maize.

The cropping system had an effect on all the characteristics used to evaluate green corn yield. Monocropped maize had higher total weight, number of green ears, and weight and number of marketable green ears, both with and without husks (Table 3). However, the weight and number of marketable husked ears of maize intercropped with gliricidia did not differ from monocropped maize (Table 3 ).

Evaluation of the dry maize characteristics showed that the cropping system had an effect only on the number of ears per hectare. The maize monocrop produced

Revista Árvore, Viçosa-MG, v.40, n.4, p.679-688, 2016 
Table 3 - Averages for green ear yield and grain and component yield for the maize cultivar AG 1051 under monocropping and intercropping with two tree species.

Tabela 3 - Médias do rendimento de espigas verdes e do rendimento de grãos e seus componentes da cultivar de milho AG 1051, em monocultivo e em consorciação com duas espécies arbóreas.

\begin{tabular}{|c|c|c|c|c|c|c|}
\hline \multirow[t]{3}{*}{ Cropping system } & \multicolumn{6}{|c|}{ Green ears ha-1 } \\
\hline & \multicolumn{2}{|c|}{ Totals } & \multicolumn{2}{|c|}{ Marketable with husks } & \multicolumn{2}{|c|}{ Marketable husked } \\
\hline & Number & Weight $(\mathrm{kg})$ & Number & Weight (kg) & Number & Weight (kg) \\
\hline Maize + gliricidia & $36,574 \mathrm{~b}$ & $11,145 \mathrm{~b}$ & $32,478 \mathrm{~b}$ & $10,407 \mathrm{~b}$ & $27,570 \mathrm{ab}$ & $5,792 \mathrm{ab}$ \\
\hline Maize + sabiá & $35,671 \mathrm{~b}$ & $10,476 \mathrm{~b}$ & $30,955 \mathrm{~b}$ & $9,691 \mathrm{~b}$ & $24,284 \mathrm{~b}$ & $4,958 \mathrm{~b}$ \\
\hline Maize & $48,075 \mathrm{a}$ & $14,112 \mathrm{a}$ & $41,783 \mathrm{a}$ & $12,880 \mathrm{a}$ & $33,695 \mathrm{a}$ & $6,753 \mathrm{a}$ \\
\hline \multirow[t]{2}{*}{$\overline{C V(\%)}$} & 3.5 & 7.9 & 8.3 & 10.9 & 15.4 & 16.3 \\
\hline & \multicolumn{6}{|c|}{ Grain yield and its components } \\
\hline Cropping system & \multicolumn{2}{|c|}{ Grain yield $\left(\mathrm{kg} \mathrm{ha}^{-1}\right)$} & of ears ha-1 & \multicolumn{2}{|c|}{ Number of grains ear ${ }^{-1}$} & ain weight $(\mathrm{g})$ \\
\hline$\overline{\text { Maize }+ \text { gliricidia }}$ & \multicolumn{2}{|c|}{$5,618 \mathrm{a}$} & $601 \mathrm{~b}$ & \multicolumn{2}{|c|}{$492 \mathrm{a}$} & $29.9 \mathrm{a}$ \\
\hline Maize + sabiá & \multicolumn{2}{|c|}{$5,162 \mathrm{a}$} & $013 \mathrm{~b}$ & \multicolumn{2}{|c|}{$492 \mathrm{a}$} & $30.4 \mathrm{a}$ \\
\hline Maize & \multicolumn{2}{|c|}{$6,714 \mathrm{a}$} & $453 \mathrm{a}$ & \multicolumn{2}{|c|}{$482 \mathrm{a}$} & $28.9 \mathrm{a}$ \\
\hline $\mathrm{CV}$ & \multicolumn{2}{|c|}{17.3} & 4.0 & \multicolumn{2}{|l|}{4.3} & 8.7 \\
\hline
\end{tabular}

For each characteristic, averages followed by the same letter do not differ at $5 \%$ probability by Tukey's test.

Em cada característica, médias seguidas pela mesma letra não diferem entre si, a 5\% de probabilidade, pelo teste de Tukey.

more ears ha-1 than intercropped maize, with no difference due to tree species (Table 3). Intercropped maize had higher number of grains ear ${ }^{-1}$ and 100 -grain weight than monocropped maize, although these differences were not significant (Table 3 ).

The cost of planting gliricidia in an intercropping system to produce green corn was $\mathrm{R} \$-4,380.16$ (Table 4). The negative sign indicates a reduction in total cost by introducing gliricidia. Cultivating maize between the rows not only covered the costs of introducing gliricidia but also produced a financial return. The cost of planting gliricidia intercropped with maize (per hectare) for grain production was $\mathrm{R} \$ 92.95$, which represents a reduction of $92.38 \%$ compared to the gliricidia monocrop (Table 4). The cost of planting sabiá for green corn production was $\mathrm{R} \$-3,866.88$, indicating a total reduction in the set-up costs for sabiá. The set-up cost per hectare of sabiá intercropped with maize for grain production was $\mathrm{R} \$ 334.37$, equivalent to a reduction of $72.39 \%$ compared to the sabiá monocrop.

After harvesting the ripe corn, the tree species continued to grow, in terms of plant height and of canopy and stem diameter, during 2010 (Table 2). This suggests tolerance to drought since rainfall was only $35.1 \mathrm{~mm}$ from September to December 2010. As in the previous year, the cropping system had no effect on plant height or ear height for maize. Averages for plant height (CV $=4.5 \%)$ and ear height $(\mathrm{CV}=6.2 \%)$ were $210 \mathrm{~cm}$ and
$118 \mathrm{~cm}$, respectively.

The cropping system only affected total weight and number of green ears (Table 5). Total weight and number of ears of legumes cut down to $0.5 \mathrm{~m}$ from the ground level was greater (on average) for maize under monocropping than for intercropping, most likely due to the larger population of monocropped maize. It is likely that the leaf waste from gliricidia and sabiá that was added to the soil after these species were pruned contributed to improve ear size and to increase the proportion of marketable ears under intercropping with the pruned trees. There were no differences between the cropping systems in number and weight of marketable ears, both with and without husks.

The chemical analysis of trimmings from gliricidia and sabiá, at the time they were added to the soil, had the following respective results: $\mathrm{C}=16.77$ and 32.23 $\mathrm{g} \mathrm{kg}^{-1} ; \mathrm{P}=0.78$ and $1.47 \mathrm{~g} \mathrm{~kg}^{-1} ; \mathrm{K}=3.49$ and $16.24 \mathrm{~g}$ $\mathrm{kg}^{-1}, \mathrm{Ca}=18.61$ and $9.94 \mathrm{~g} \mathrm{~kg}^{-1} ; \mathrm{Mg}=6.02$ and 8.34 $\mathrm{g} \mathrm{kg}^{-1} ; \mathrm{Cu}=221.87$ and $115.07 \mathrm{mg} \mathrm{L}^{-1} ; \mathrm{Mn}=10.75$ and $16.40 \mathrm{mg} \mathrm{L}^{-1} ; \mathrm{Fe}=73.10$ and $124.62 \mathrm{mg} \mathrm{L}^{-1} ; \mathrm{Zn}=8.70$ and $3.72 \mathrm{mg} \mathrm{L}^{-1}$.

Maize yield is increased by the application of plant residues from other crops (CARVALHO et al., 2008). The average dry weights of gliricidia and sabiá leaf waste added to the soil were 459 and $684 \mathrm{~kg} \mathrm{ha}^{-1}$, 
Table 4 - Costs of planting two legumes and of producing corn (Taungya system, in 2010), of producing corn under monocropping and intercropping with two tree species, pruned when the maize was sown (alley cropping, in 2011), and income from commercializing marketable green ears and corn grain.

Tabela 4 - Custos do plantio de duas espécies arbóreas e de produção de milho (sistema taungya, em 2010), custos de produção de milho, em monocultivo e em consorciação com duas espécies arbóreas, podadas quando o milho foi semeado (sistema de aleias, em 2011), e renda com a comercialização das espigas verdes e grãos do milho.

\begin{tabular}{|c|c|c|c|c|c|c|c|}
\hline \multicolumn{8}{|c|}{ 2010: Taungya system } \\
\hline \multirow[t]{3}{*}{ Production system } & \multicolumn{3}{|c|}{ Costs } & \multicolumn{2}{|c|}{$\begin{array}{l}\text { Total income }(\mathrm{TI}) \\
\text { from corn sale }\end{array}$} & \multicolumn{2}{|c|}{$\begin{array}{c}\text { Net income (TI - TC) } \\
\text { from corn sale }\end{array}$} \\
\hline & $\begin{array}{l}\text { Introduction } \\
\text { of legumes } \\
\text { (CIL) }\end{array}$ & $\begin{array}{l}\text { Corn } \\
\text { production } \\
(\mathrm{CPC})\end{array}$ & $\begin{array}{l}\text { Total }(\mathrm{TC}) \\
=\mathrm{CIL}+ \\
\quad \mathrm{CPC}\end{array}$ & $\begin{array}{l}\text { Green } \\
\text { ears }\end{array}$ & Grain & $\begin{array}{l}\text { Green } \\
\text { ears }\end{array}$ & Grain \\
\hline & \multicolumn{7}{|c|}{$\mathrm{R} \$ \mathrm{ha}^{-1}$} \\
\hline Gliricidia + maize for production of green corn & $1,220.15$ & $1,996.65$ & $3,216.80$ & $7,596.96$ & - & $-4,380.16$ & - \\
\hline Gliricidia + maize for production of corn grain & $1,220.15$ & $1,962.81$ & $3,182.96$ & - & $3,090.01$ & - & -92.95 \\
\hline Sabiá + maize for production of green corn & $1,210.55$ & $1,996.65$ & $3,207.20$ & $7,074.08$ & - & $-3,866.88$ & - \\
\hline Sabiá + maize for production of grain & $1,210.55$ & $1,962.81$ & $3,173.36$ & - & $2,838.99$ & - & -334.37 \\
\hline \multicolumn{8}{|c|}{ 2011: alley cropping } \\
\hline \multirow[t]{3}{*}{ Production system } & \multicolumn{3}{|c|}{$\begin{array}{l}\text { Total production cost (TC) for } \\
\text { maize, pruning the legumes and } \\
\text { incorporating the biomass }\end{array}$} & \multicolumn{2}{|c|}{$\begin{array}{l}\text { Total income }(\mathrm{TI}) \\
\text { rom corn sale }\end{array}$} & \multicolumn{2}{|c|}{$\begin{array}{l}\text { Net income } \\
(\mathrm{TI}-\mathrm{TC})\end{array}$} \\
\hline & & & & Green ears & Grain & Green ears & Grain \\
\hline & & & & $-\mathrm{R} \$ \mathrm{ha}^{-1}$ & & & \\
\hline \multicolumn{2}{|l|}{ Pruned gliricidia + maize for production of green corn } & $2,040.05$ & & $6,202.81$ & - & $4,162.76$ & - \\
\hline \multicolumn{2}{|l|}{ Pruned gliricidia + maize for production of grain } & $1,864.06$ & & - & $1,921.70$ & - & 57.64 \\
\hline \multicolumn{2}{|l|}{ Pruned sabiá + maize for production of green corn } & $2,094.56$ & & $6,233.47$ & - & $4,138.91$ & - \\
\hline \multicolumn{2}{|l|}{ Pruned sabiá + maize for production of grain } & $1,918.56$ & & - & $1,993.75$ & - & 75.19 \\
\hline \multicolumn{2}{|l|}{ Maize monocrop for production of green corn } & $2,224.08$ & & $7,500.75$ & - & $5,276.67$ & - \\
\hline \multicolumn{2}{|l|}{ Maize monocrop for production of grain } & $1,990.14$ & & - & $2,610.30$ & - & 620.16 \\
\hline
\end{tabular}

respectively. Although the difference between these weights were not significant $(\mathrm{CV}=26.5 \%)$, it is interesting to note that the average yield for green ears obtained under intercropping with sabiá was higher than the average under intercropping with gliricidia. Similarly to what was observed for total number of green ears and grain yield, the cropping system had an effect on number of ears for dry corn. The number of mature ears and grain yield were greater for monocropping than for intercropping with the pruned legumes (Table 5), in accordance with Queiroz et al. (2007).

Producing green ears is more advantageous than producing grain for maize under monocropping or alley cropping (Table 5). However, monocropping has a greater net income than alley cropping for maize, for producing both green corn and grain (Table 4 ).

\section{DISCUSSION}

Intercropping increased plant height only for sabiá (Table 1), most likely due to competition with maize for light. Crops elicit responses when competing for light, including the development of characteristics to avoid shade, such as a low root to shoot ratio and strong apical dominance with a low branching rate. These characteristics promote growth of the stem height (KEGGE; PIERIK, 2009). The morphological changes that take place to avoid shade occur prior to shading (RAJCAN et al., 2004). Because maize grew faster than legumes, at least in terms of plant height (see data below and Table 2 for comparison), some shading must have occurred. Marques (1990) noted that stem growth in height and diameter for three forest species was favored under intercropping with maize and Brachiaria Brizantha (Hochst. ex A. Rich.) Stapf.

The cropping system had an effect on all the characteristics used to evaluate green corn yield (Table 3 ). This was most likely due to a greater plant population of monocropped maize $(50,000$ plants ha-1) compared to intercropped maize $\left(37,500\right.$ plants $\left.^{-1} \mathrm{a}^{-1}\right)$, although some competition for light, water and nutrients may have also occurred. This explanation was offered by other studies

Revista Árvore, Viçosa-MG, v.40, n.4, p.679-688, 2016 
Table 5 - Averages for green ear yield and grain and component yield for the maize cultivar AG 1051 under monocropping and intercropping with two tree species cut down to $0.5 \mathrm{~m}$ from the ground level at the time when maize was sown.

Tabela 5 - Médias do rendimento de espigas verdes e do rendimento de grãos e seus componentes da cultivar de milho AG 1051, em monocultivo e em consorciação com duas espécies arbóreas, cortadas a 0,5 m da superfície do solo à época em que o milho foi semeado.

\begin{tabular}{|c|c|c|c|c|c|c|}
\hline \multirow[t]{3}{*}{ Cropping system } & \multicolumn{6}{|c|}{ Green ears ha ${ }^{-1}$} \\
\hline & \multicolumn{2}{|c|}{ Totals } & \multicolumn{2}{|c|}{ Marketable with husks } & \multicolumn{2}{|c|}{ Marketable husked } \\
\hline & Number & Weight (kg) & Number & Weight $(\mathrm{kg})$ & Number & Weight $(\mathrm{kg})$ \\
\hline$\overline{\text { Maize }+ \text { cut gliricidia }}$ & $36,829 \mathrm{~b}$ & $9,487 \mathrm{~b}$ & 28,385 a & 8,497 a & 23,800 a & $5,215 \mathrm{a}$ \\
\hline Maize + cut sabiá & $36,999 \mathrm{~b}$ & $10,011 \mathrm{~b}$ & $28,257 \mathrm{a}$ & 8,539 a & 24,666 a & $5,036 \mathrm{a}$ \\
\hline Maize & 49,539 a & $12,885 \mathrm{a}$ & 34,382 a & $10,275 \mathrm{a}$ & 31,721 a & 6,414 a \\
\hline \multirow{2}{*}{$\overline{\mathrm{CV}, \%}$} & 3.7 & 11.6 & 16.8 & 19.2 & 21.2 & 18.9 \\
\hline & \multicolumn{6}{|c|}{ Grain yield and its components } \\
\hline Cropping system & \multicolumn{2}{|c|}{ Grain yield $\left(\mathrm{kg} \mathrm{ha}^{-1}\right)$} & of ears ha-1 & \multicolumn{2}{|c|}{ Number of grains ear ${ }^{-1}$} & ain weight $(\mathrm{g})$ \\
\hline$\overline{\text { Maize }+ \text { cut gliricidia }}$ & \multicolumn{2}{|c|}{$3,494 \mathrm{~b}$} & $406 \mathrm{~b}$ & \multicolumn{2}{|l|}{$524 \mathrm{a}$} & $20,7 \mathrm{a}$ \\
\hline Maize + cut sabiá & \multicolumn{2}{|c|}{$3,625 \mathrm{~b}$} & $628 \mathrm{~b}$ & & $23,1 \mathrm{a}$ \\
\hline Maize & \multicolumn{2}{|c|}{$4,746 \mathrm{a}$} & $591 \mathrm{a}$ & \multicolumn{2}{|l|}{$478 \mathrm{a}$} & $21,2 \mathrm{a}$ \\
\hline$\overline{\mathrm{CV}, \%}$ & \multicolumn{2}{|c|}{14.3} & 8.0 & \multicolumn{2}{|l|}{7.6} & 12.7 \\
\hline
\end{tabular}

1 For each characteristic, averages followed by the same letter do not differ at $5 \%$ probability by Tukey's test.

1 Em cada característica, médias seguidas pela mesma letra não diferem entre si, a 5\% de probabilidade, pelo teste de Tukey.

with similar results (MARIN etal., 2007). However, weight and number of marketable husked ears did not differ between maize intercropped with gliricidia and monocropped maize (Table 3 ). This suggests that intercropping with gliricidia was beneficial to the maize for at least two reasons. Firstly, gliricidia controls weeds (SILVA et al., 2010). Secondly, there may have been a transfer of $\mathrm{N}$ (fixed by bacteria in gliricidia) to the maize, as shown in other combinations of grass and legumes (DIAS et al., 2007). It is unclear why similar results were not obtained with sabiá. Information on weed control by sabiá could not be found in the literature, however different species of leguminous arboreal plants are known to differ in their abilities to control weeds (KAMARA et al., 2000) and to transfer fixed N (DIAS et al., 2007).

Evaluation of dry maize characteristics showed that the cropping system had an effect only on number of ears ha-1 (Table 3 ). This result is certainly due to the larger plant population under monocropping compared to intercropping. Differences in grain yield between treatments may not have been detected due to low experimental precision $(\mathrm{CV}=17.4 \%)$ compared to the precision of number of ears ha-1 (Table 3 ). There is a trade-off in component production under conditions of stress (ECK, 1986), similar to what occurs when competition exists under intercropping. Although the differences were not significant, intercropped maize exhibited a higher number of grains ear ${ }^{-1}$ and a higher 100-grain weight than monocropped maize (Table 3 ). Finally, it should be noted that the trade-off in yield components may be different under monocropping and intercropping (EGBE; ADEYEMO, 2006).

The different effects that cropping systems had on green ear and grain yields (Table 3) may be due to two causes. Mature ears spend more time in the field than green ears, which can reduce or enhance the beneficial effects (transfer of fixed $\mathrm{N}$ by the legumes, for example) or harmful effects (competition) of the intercropped trees. Furthermore, unmarketable green ears can be used for the production of dry grain.

Several studies have previously reported the economic benefits observed under the Taungya system (Table 4) (RODRIGUES et al., 2007; DARONCO et al., 2012).

The alley cropping system affected differently green ear yield and grain yield (Table 5). As previously mentioned, discarded green ears can be used for evaluating grain yield. Moreover, the maize used for dry grain production spends more time in the field and may be subject to more intense competition with legumes. It is worth mentioning that although pruned, the legumes grew new shoots, and may have competed for water, light and nutrients under intercropping. As expected, more rigorous pruning of the tree species improves 
grain yield for maize grown under intercropping (BERTOMEU et al., 2011).

\section{CONCLUSIONS}

Gliricidia had lower plant height than sabiá. Moreover, while not affecting for gliricidia, intercropping increased plant height for sabiá. Intercropping reduced green ear yield but not grain yield, and reduced the cost of reforestation. In the alley system, intercropping reduced the total number and mass of green ears, as well as the grain yield, but did not influence the yield of marketable green ears. Finally, producing green ears was more profitable than producing grain and monocropping provided a higher net income for the two products.

\section{REFERENCES}

BARTLETT, M.S. Some examples of statistical methods of research in agriculture and applied biology. Journal of Royal Statistical Society, v.4, n.1, p.137-183, 1937.

BERTOMEU, M.; ROSHETKO, J.M.; RAHAYU, S. Optimum pruning intensity for reducing crop suppression in a Gmelina-maize smallholder agroforestry system in Claveria, Philippines. Agroforestry Systems, v.83, n.2, p.167-180, 2011 .

COMPANHIA NACIONAL DE ABASTECIMENTO - CONAB. Custos de produção agrícola: a metodologia da CONAB. Brasília: 2010. 60p.

CARMO FILHO, F.; OLIVEIRA, O.F. Mossoró: um município do semi-árido nordestino. Mossoró: Fundação Guimarães Duque/ESAM, 1989. 62p. (Col. Mossoroense, B, 672).

CARVALHO, M.C.; BUSTAMANTE, M.M.C.; SOUSA JUNIOR, J.G.A.; VIVALDI, L.J.

Decomposição de resíduos vegetais em Latossolo sob cultivo de milho e plantas de cobertura. Revista Brasileira de Ciência do Solo, v.32, p.2831-2838, 2008. (Número Especial)

CASTELLETTI, C.H.M.; SILVA, J.M.C.; TABARELLI, M.; SANTOS, A.M.M. Quanto ainda resta da Caatinga? Uma estimativa preliminar. In: SILVA, J.M.C.; TABARELLI, M.; FONSECA, M.T.; LINS, L.V. (Org.)
Biodiversidade da Catinga: áreas e ações prioritárias para a conservação. Brasília: Ministério do Meio Ambiente, 2004. p.91-100.

DARONCO, C.; MELO, A.C.G.; MACHADO, J.A.R. Consórcio de espécies nativas da floresta estacional semidecidual com mandioca (Manihot esculenta Crantz) para restauração de mata ciliar. Revista Árvore, v.36, n.2, p.291-299, 2012.

DIAS, P.F.; SOUTO, S.M.; RESENDE, S.U.; URQUIAGA, S.; ROCHA, G.P.; MOREIRA, J.F.; FRANCO, A.A. Transferência do $\mathrm{N}$ fixado por leguminosas arbóreas para o capim Survenola crescido em consórcio. Ciência Rural, v.37, n.2, p.352-356, 2007.

ECK, H.V. Effects of water deficits on yield, yield components, and water use efficiency of irrigated corn. Agronomy Journal, v.78, n.6, p.1035$1040,1986$.

EGBE, O.M.; ADEYEMO, M.O. Estimation of the effect of intercropped pigeon pea on the yield and yield components of maize in Southern Guinea Savannah of Nigeria. Journal of Sustainable Development in Agriculture and Environment, v.2, n.1, p.107-113, 2006.

EHIAGBONARE, J.E. Effect of taungya on regeneration of endemic forest tree species in Nigeria: Edo State Nigeria as a case study. African Journal of Biotechnology, v.5, p.1608-1611, 2006.

EMPRESA BRASILEIRA DE PESQUISA AGROPECUÁRIA - EMBRAPA. Centro Nacional de Pesquisa do Solo. Sistema brasileiro de classificação de solos. Brasília: Serviço de Produção de Informação, 2006. 306p

FERREIRA, D.F. SISVAR - Programa estatístico. Versão 5.3 (Build 75). Lavras: Universidade Federal de Lavras, 2010.

FOOD AND AGRICULTURE ORGANIZATION OF THE UNITED NATIONS - FAO. Soil map of the world: revised legend. Rome: UNESCO, 1988. 119p.

IMO, M. Interactions amongst trees and crops in taungya systems of western Kenya. Agroforestry Systems, v.76, n.2, p.265-273, 2009.

Revista Árvore, Viçosa-MG, v.40, n.4, p.679-688, 2016

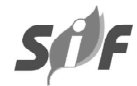


JANDEL. Jandel TBLCURVE. Table Curve 3.0. Curve fitting software. Corte Madera: Jandel Scientific, 1992. 280p.

KAMARA, A.Y.; AKOBUNDU, I.O.; CHIKOYE, D.; JUTZI, S.C. Selective control of weeds in an arable crop mulches from some multipurpose trees in Southwestern Nigeria. Agroforestry Systems, v.50, n.1, p.17-26, 2000.

KARIM, A.B.; SAVILL, P.S.; RHODES, E.R. The effects of between-row (alley widths) and withinrow spacings of Gliricidia sepium on alleycropped maize in Sierra Leone. Agroforestry Systems, v.24, n.1, p.81-93, 1993.

KEGGE, W.; PIERIK, R. Biogenic volatile organic compounds and plant competition. Trends in Plant Science, v. 15, n.3, p.126-132, 2009.

KIILL, L.H.P.; MENEZES, E.A. (Ed.). Espécies vegetais exóticas com potencialidades para o Semi-Árido brasileiro. Brasília: Embrapa Informação Tecnológica, 2005. 340p.

KÖPPEN, W. Climatologia; con un estudio de los climas de la tierra. México: Fondo de Cultura Economica, 1948. 478p.

LEAL, I.R.; SILVA, J.M.C.; TABARELLI, M.; LACHER JÚNIOR, T.E. Mudando o curso da conservação da biodiversidade na Caatinga do Nordeste do Brasil. Megadiversidade, v.1, n.1, p.139-146, 2005.

LILLIEFORS, H.W. on the Kolmogorov-Smirnov test for normality with mean and variance unknown. Journal of the American Statistical Association, v.62, n.318, p.399$402,1967$.

MARIN, A.M.P.; MENEZES, R.S.C.; SALCEDO, I.H. Produtividade do milho solteiro ou em aléias de gliricídia adubado com duas fontes orgânicas. Pesquisa Agropecuária Brasileira, v.42, n.5, p.669-677, 2007.

MARQUES, L. C. T. Comportamento inicial de Paricá, Tatajuba e Eucalipto, em plantio consorciado com milho e capimmarandu, em Paragominas, Pará. Tese de Mestrado. UFV. Viçosa, março de 1990.

QUEIROZ, L.R.; COELHO, F.C.; BARROSO, D.G.; QUEIROZ, V.A.V. Avaliação da produtividade de fitomassa e acúmulo de N, P e K em

leguminosas arbóreas no sistema de aléias, em Campo dos Goytacazes, RJ. Revista Árvore, v.31, n.3, p.383-390, 2007.

RAJCAN, I.; CHANDLER, K.J.; SWANTON, C.J. Red-far-red ratio of reflected light: a hypothesis of why early-season weed control is important in corn. Weed Science, v.52, n.5, p.774-778, 2004.

REIS, R.P. Fundamentos de economia aplicada. Lavras: UFLA/FAEPE, 2002. 95p. (Textos Acadêmicos).

RODRIGUES, E.R.; CULLEN JR., L.; BELTRAME, T.P.; MOSCOGLIATO, A.V.; SILVA, I.C. Avaliação econômica de sistemas agroflorestais implantados para recuperação de reserva legal no Pontal do Paranapanema, São Paulo. Revista Árvore, v.31, n.5, p.941-948, 2007.

SILVA, M.L.; LÓPEZ, J.C.F.; ALVES, J.U.; PASSOS, C.A. Avaliação econômica de sistemas agroflorestais com eucalipto-arroz e eucalipto-feijão no município de Divinópolis MG, Brasil. Revista Árvore, v.25, n.2, p.209-216, 2001.

SILVA, P.S.L.; BRAGA, J.D.; RIBEIRO, M.S.S.; OLIVEIRA, O.F.; SANTOS, T.S. Nitrogen doses and weed control via intercropping with gliricidia for corn production. Planta Daninha, v. 28, n.3, p.531-539, 2010. 